\title{
Sectioned Images of a Cat Head to Contribute to Learning of its Sectional Anatomy
}

\author{
Imágenes Seccionadas de una Cabeza de Gato para Contribuir \\ al Conocimiento de su Anatomía Seccional
}

Beom Sun Chung'; Min Suk Chung'; Seung-Bock Lee ${ }^{2}$; Cheong Youn ${ }^{3}$ \& Jin Seo Park ${ }^{4}$

CHUNG, B. S.; CHUNG, M. S.; LEE, S.B.; YOUN, C. \& PARK, J. S. Sectioned images of a cat head to contribute to learning of its sectional anatomy. Int. J. Morphol., 36(2):537-543, 2018.

SUMMARY: The sectional anatomy of a cat head is essential when interpreting CTs and MRIs of the region. In learning the sectional anatomy, sectioned images of a cat could be quite effective data. The main objective was to assist veterinary physicians who learn the sectional anatomy of a cat head by presenting high-quality sectioned images. A short-haired female cat was frozen and sectioned frontally using a cryomacrotome. Every sectioned surface in real body color was photographed with a digital camera. The frontal planes were stacked to produce dorsal and sagittal planes. High-quality sectioned images of a cat head allowed the identification of small, complicated structures. The notable structures were as follows: each bone of the cranium, structures of the brain, tympanic cavity (larger than human), oval window (larger than human), vestibular nerve, cochlear nerve, ear ossicles, six extraocular muscles, pupil (larger than human), retractor bulbi muscle (not found in human), optic nerve, olfactory bulb (considerably large), vomeronasal organ duct (not found in human), infraorbital gland (not found in human), masticatory muscles (larger than human), maxillary nerve (larger than human), and mandibular nerve. This pacesetting report describes the detailed head structures of a cat from the viewpoint of sectional anatomy. The sectioned images will be given to other interested researchers free of charge.

KEY WORDS: Cat; Head; Cross-sectional anatomy; Visible Human Projects.

\section{INTRODUCTION}

Unlike computed tomographs (CTs) and magnetic resonance images (MRIs), sectioned images of the human body in real color and with high resolution have certain advantages in learning and teaching sectional anatomy (Spitzer \& Whitlock, 1997; Dixon et al., 2015). Comparisons between the clinical images and the sectioned images are useful in many ways (Schiemann et al., 2000; Spitzer \& Scherzinger, 2006; Nowinski et al., 2012).

Cats as pets are increasing in number, so that the use of CTs and MRIs to diagnose their diseases is becoming increasingly popular (Bishop et al., 2008; Taeymans et al., 2008; Kang et al., 2009; Weidner et al., 2012). The production of sectioned images of a cat that are helpful in learning CTs and MRIs of cats is becoming increasingly necessary (Rivero et al., 2005; Lauridsen et al., 2011). Moreover, three-dimensional (3D) models made from the sectioned images of a cat would be the source of a virtual dissection and virtual operation for veterinary students and veterinary physicians. Therefore, the sectioned images of a cat have been made by other researchers. However, the sectioning intervals of the images were too thick and inconstant; their resolution was too low (http://digimorph.org). The region of interest in the present study was the cat head because the morphology and function of the head of a species is quite different from those of other species.

The objective of this research was to help the interested people learn the sectional anatomy of cat head by presenting high-quality sectioned images. The original frontal planes of a cat head were stacked to obtain the other two orthogonal planes; on the high quality planes, meaningful head structures of cat were identified and compared with those of human (Park et al., 2009).

\footnotetext{
${ }^{1}$ Department of Anatomy, Ajou University School of Medicine, 164 Worldcup-ro, Suwon, 16499, Republic of Korea.

${ }^{2}$ Scientific Data Strategy Lab., Scientific Data Research Center, Korea Institute of Science and Technology Information, 245 Daehak-ro, Daejeon, 34141 , Republic of Korea.

${ }^{3}$ College of Engineering, Chungnam National University, 99 Daehak-ro, Daejeon, 34134, Republic of Korea.

${ }^{4}$ Department of Anatomy, Dongguk University, School of Medicine, 87 Dongdae-ro, Gyeongju, 38067, Republic of Korea.
} 


\section{MATERIAL AND METHOD}

A domestic short-haired female cat (one year old; height $460 \mathrm{~mm}$; width $160 \mathrm{~mm}$; length $711 \mathrm{~mm}$ ) was purchased from a company supplying laboratory animals. This study was performed after obtaining permission from the Institutional Animal Care and Use Committee of Ajou University School of Medicine (No. AMC104).
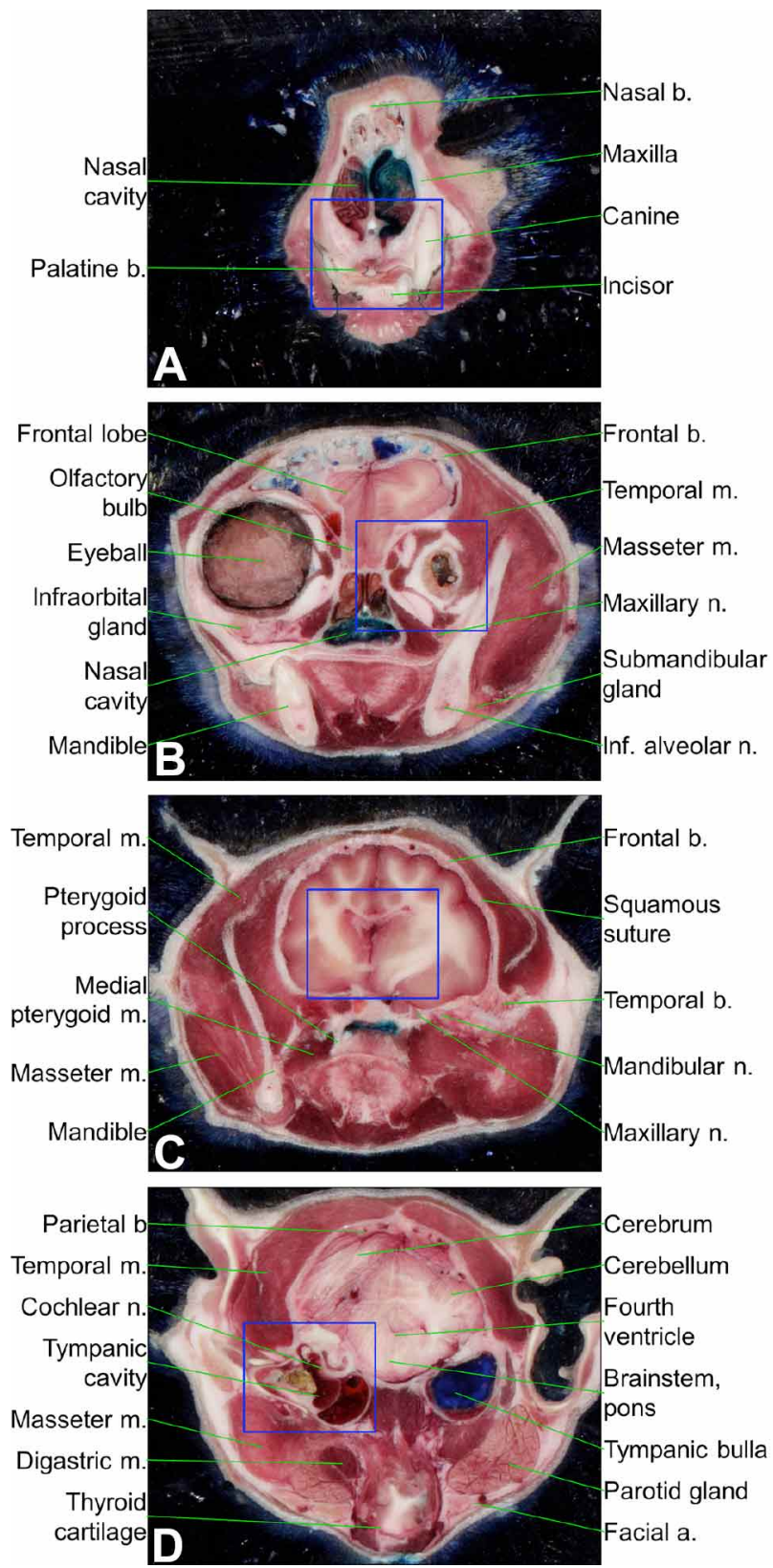

The subject was sacrificed by an injection of potassium chloride $(\mathrm{KCl} ; 100 \mathrm{mg} / \mathrm{ml})$. Neither fixative nor dye was injected into the subject. After freezing in a $-70{ }^{\circ} \mathrm{C}$ freezer, the whole body of a cat was positioned in the embedding box with a gelatin solution to be sectioned frontally. Using a cryomacrotome, the cat was ground serially, cranial to caudal, at $0.2 \mathrm{~mm}$ intervals to produce sectioned surfaces, as done previously with human cadaver (Park et al., 2005).
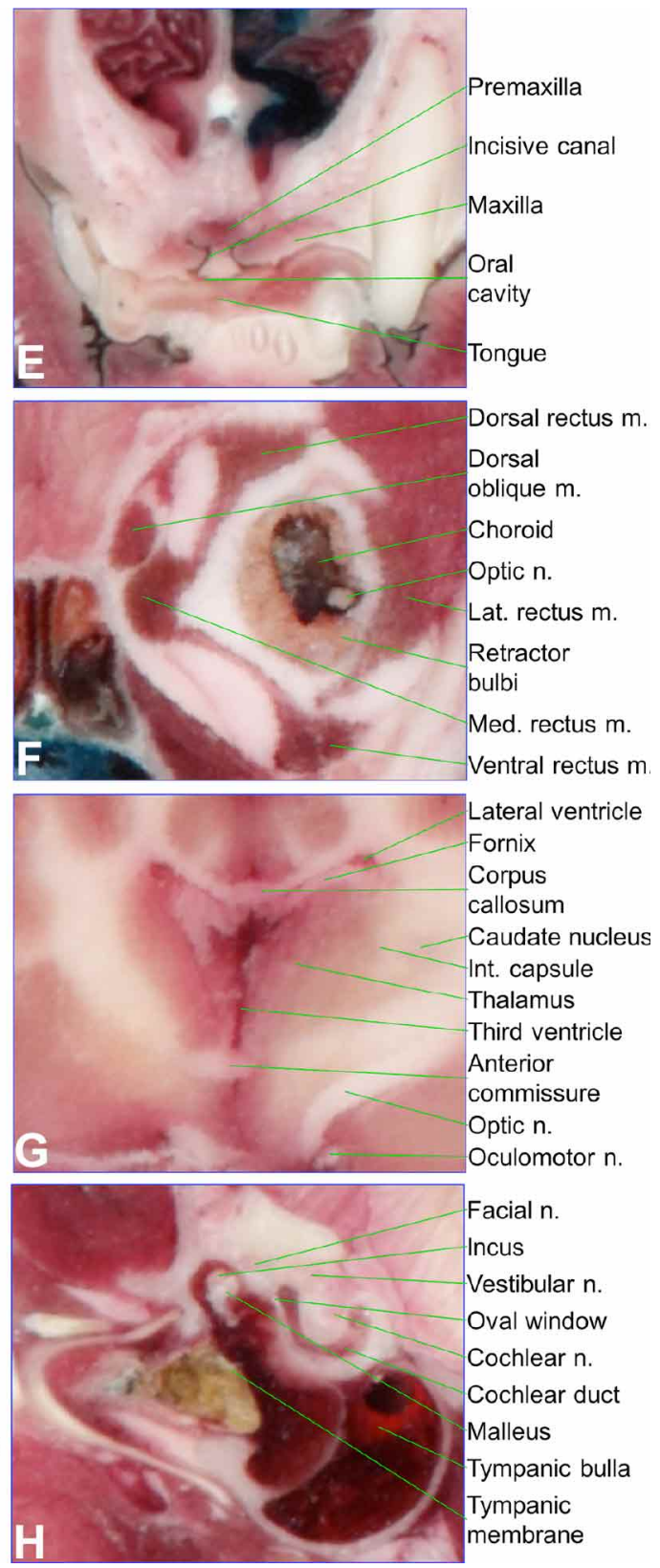

Fig. 1. Frontal sectioned images of a cat head. In (A-D) original and (E-H) magnified sectioned images on the level of nose $(A, E)$, eye $(B, F)$, cerebrum $(C, G)$, and ear $(D, H)$, detailed structures of cat are identified. $b .=$ bone; $\mathrm{m} .=$ muscle; n. = nerve; a. = artery; inf. $=$ inferior; lat. = lateral; med. = medial; int. = internal. 
Table I. Features of the three orthogonal planes of a cat head.

\begin{tabular}{llllll}
\hline Planes & Intervals & Numbers & Resolution & Pixel size & Bit depth \\
\hline Frontal & $0.2 \mathrm{~mm}$ & 466 & $1,154 \times 928$ & $0.1 \mathrm{~mm}$ & 48 bit color \\
Dorsal & $0.2 \mathrm{~mm}$ & 464 & $577 \times 466$ & $0.2 \mathrm{~mm}$ & 24 bit color \\
Sagittal & $0.2 \mathrm{~mm}$ & 577 & $464 \times 466$ & $0.2 \mathrm{~mm}$ & 24 bit color \\
\hline
\end{tabular}

Each sectioned surface was photographed using a Canon $^{\mathrm{TM}}$ EOS-1Ds Mark III digital camera (resolution 5,616 X 3,328; color depth 48 bit color) equipped with a Canon ${ }^{\mathrm{TM}}$ EF $50 \mathrm{~mm} \mathrm{f} / 1.2 \mathrm{~L}$ USM lens. At that time, the sectioned surface was flashed by two Elinchrom ${ }^{\mathrm{TM}}$ Digital S strobes, connected to an Elinchrom ${ }^{\mathrm{TM}}$ Digital 2 power pack. The captured image (pixel size $0.1 \mathrm{~mm}$ ) was saved in tagged image file format (TIFF) (Park et al., 2014). By repeating the procedure, 2,901 frontal sectioned images of the whole cat body were made. Among them, 466 images of the head were chosen; the excessive margins were cropped for this research (Fig. 1) (Table I).

The pixel size of the frontal planes was increased from $0.1 \mathrm{~mm}$ to $0.2 \mathrm{~mm}$ to standardize the pixel size to the sectioning interval; their bit depth was lowered from 48 bits color to 24 bit color. Using self-developed software, the frontal planes were stacked to produce dorsal and sagittal planes (Fig. 2) (Table I) (Park et al., 2010).

The three orthogonal planes of a cat head were observed minutely in conformity with the subregions. Furthermore, the sectioned images were compared with those of a human head (Park et al., 2009). If necessary, the length of a structure was measured according to the number of pixels on Photoshop CS6 (Adobe Systems, Inc., San Jose, CA, USA).

\section{RESULTS}

In the case of the original sectioned images of the cat, the file size of a single image was 32 MBytes and the total file size of the images of the whole body was 91.7 GBytes. In this study, images of the head region that were reduced in quantity were used. Consequently, the file sizes of single and total images were 3 Mbytes and 1.4 GBytes, respectively.

Cranium. Each bone of the cat cranium was identifiable by sutures. For example, on the lateral side of the cranium, the parietal and temporal bones were demarcated by a squamous suture. Unlike human, cat had a supernumerary bone, premaxilla in the front of the maxilla (Fig. 1A, E). In dog, the bone is called the incisive bone, and is usually long because of the protruded snout (Evans \& Alexander, 2012).
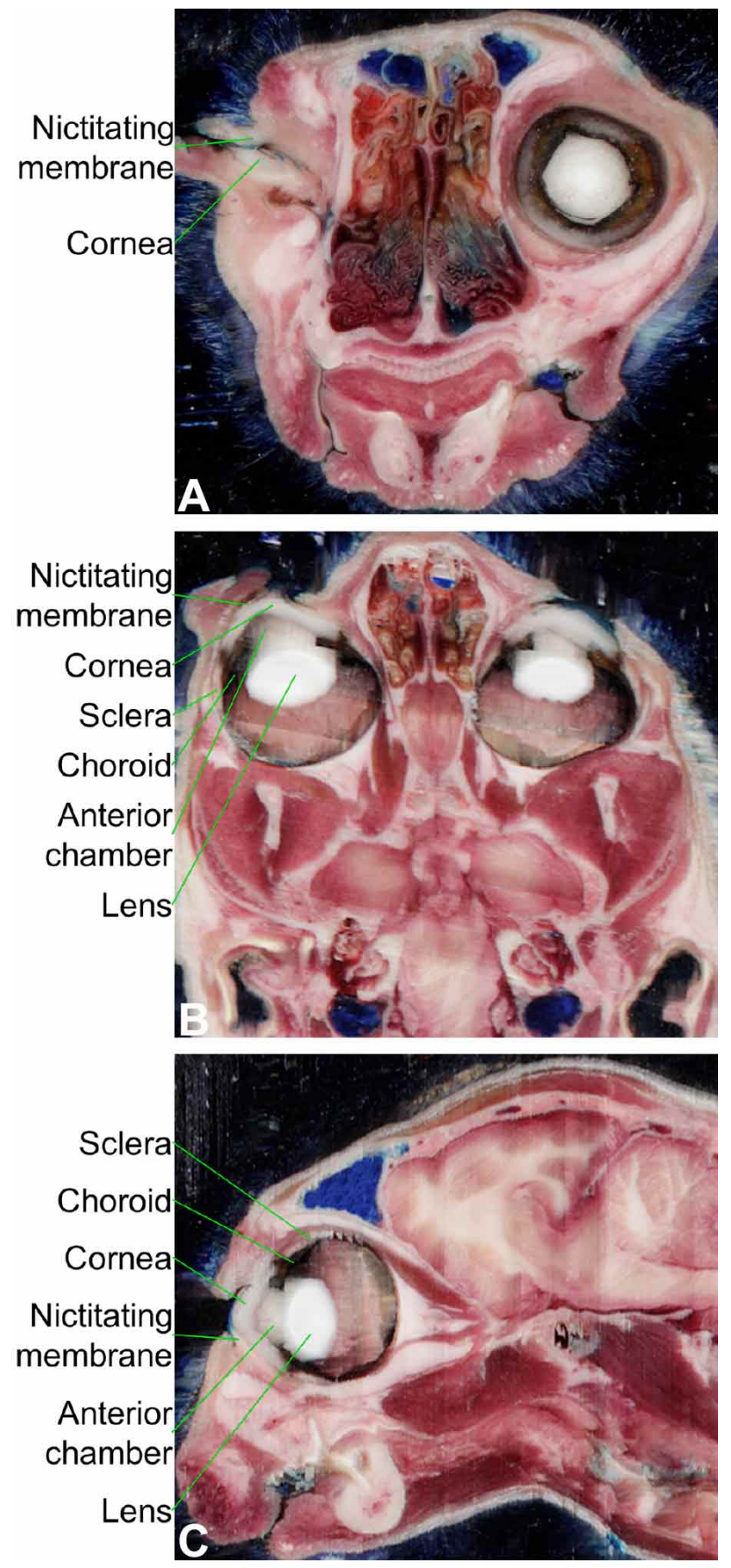

Fig. 2. Sectioned images of three orthogonal planes passing the eyeball. In (A) frontal, (B) dorsal, and (C) sagittal sectioned images, eye structures including the eyelid and anterior chamber are shown. 

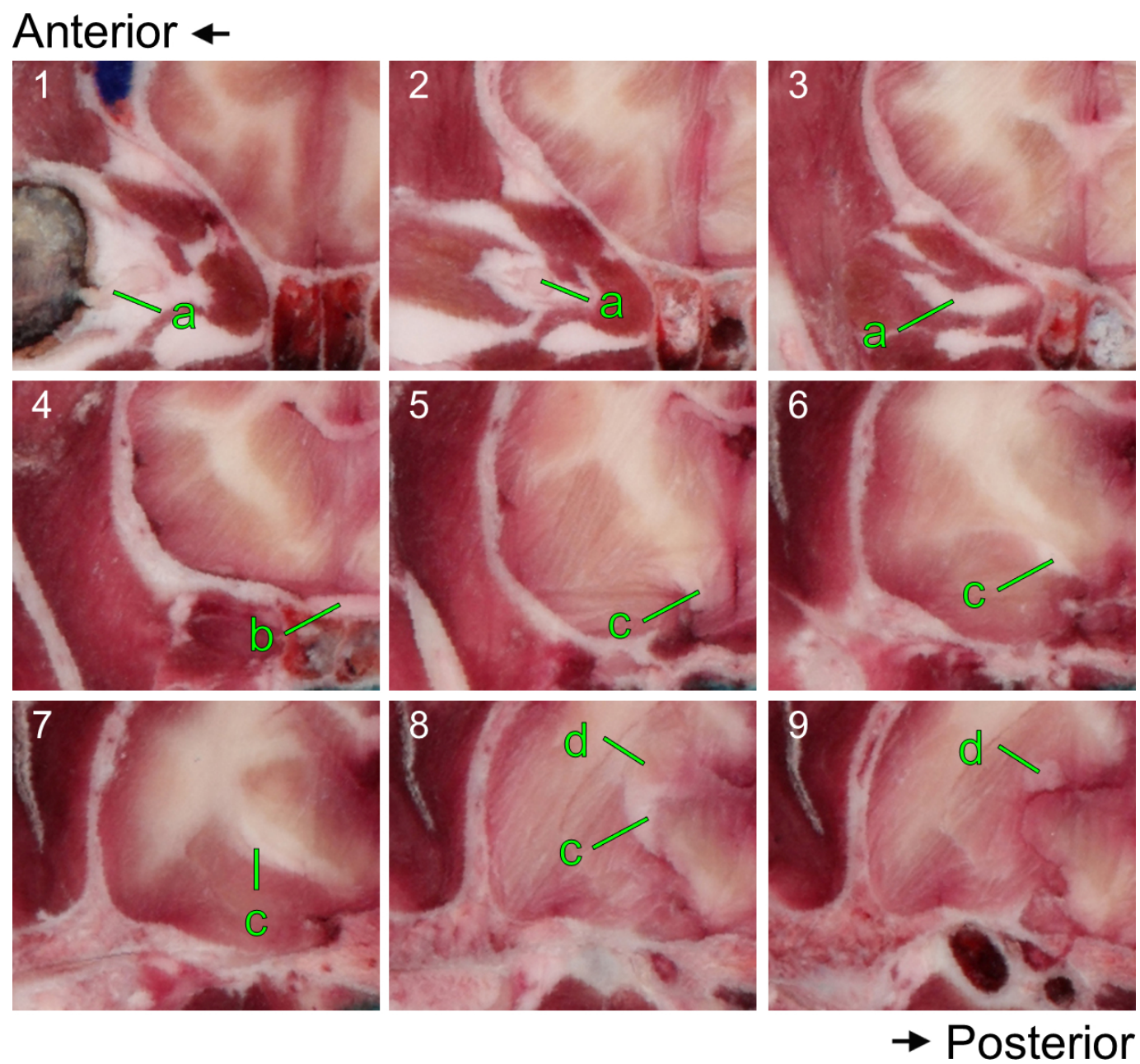

Fig. 3. Visual pathway on frontal sectioned images. Visual pathway from the eyeball to the lateral geniculate nucleus.

Brain. Under the corpus callosum, other white matter (fornix, caudate nucleus, and internal capsule) could be observed. As an artifact, the lateral and third ventricles were collapsed with the cerebrospinal fluid discharged (Fig. 1C, G).

Ear. Cat had a larger tympanic cavity than human. In its tympanic cavity, the malleus, incus, and stapes were connected; a synovial joint between the malleus and incus was observed. The ratio of the largest length of the tympanic membrane and the oval window in the cat was approximately seventeen (Sebastiani \& Fishbeck, 2005), while that in human was approximately ten (Jang et al., 2011; Park et al., 2013). This suggests that cats can collect sound well. The vestibular nerve and cochlear nerve were observed in the cochlea (Fig. 1D, H).

Eye. In the orbit of the cat, four rectus muscles and two oblique muscles could be observed just like human. Cat had one more muscle, retractor bulbi muscle, which retracts the eyeball. When the retractor bulbi muscle contracts, the nictitating membrane (third eyelid) is closed as a protective mechanism (Fig. 1B, F; Fig. 2). The nictitating membrane exists in many mammals, including dog (Sebastiani \& Fishbeck; Evans \& Alexander), but is vestigial in human (Grant et al., 1979).

Cat had a large pupil in the eyeball to make a broad visual field. Compared to human, the large pupil makes it possible to perceive light of only one-sixth the intensity (Wilcox \& Barlow, 1975). The cat's cornea was more curved, so that the anterior chamber was greater, which gives rise to higher refraction of light (Fig. 2) (Sebastiani \& Fishbeck). In the center of the retractor bulbi muscles, the optic nerve was identified. The optic nerve passing optic canal ran from the eyeball to the optic chiasm; the optic tract ran from the optic chiasm to the lateral geniculate nucleus; the optic 

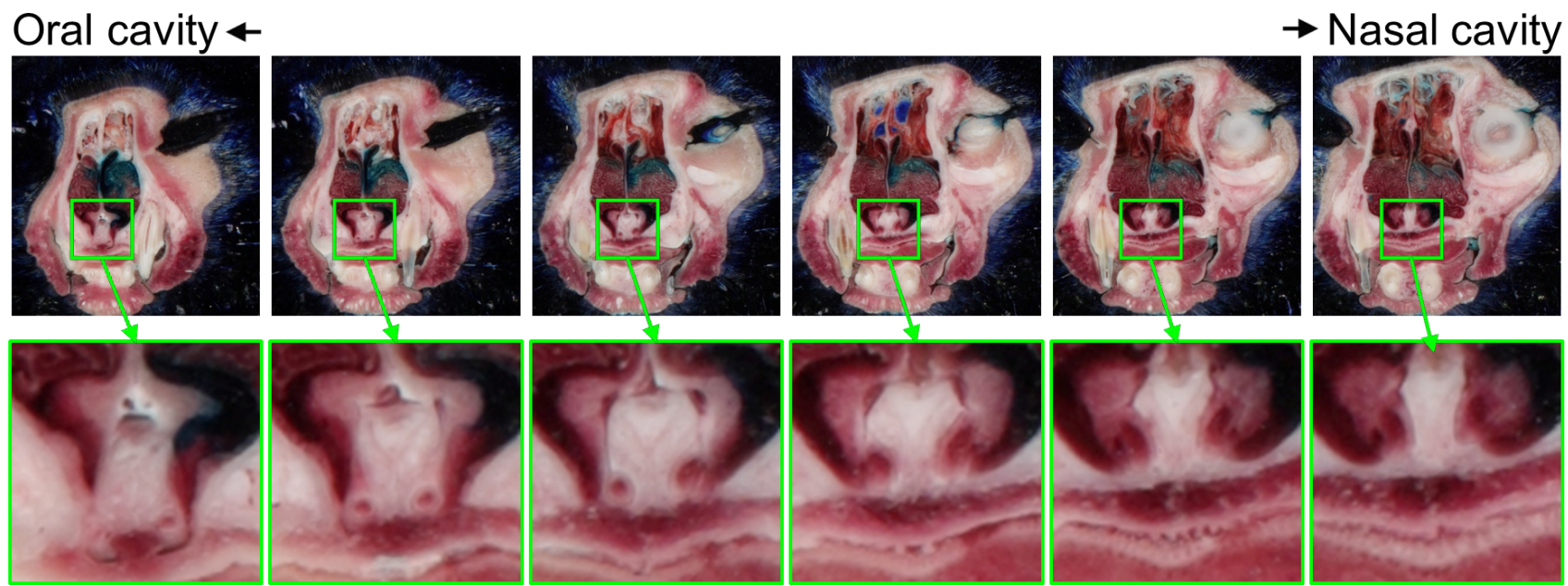

Fig. 4. Vomeronasal duct on the frontal sectioned images. On the images from the oral to nasal cavities, the vomeronasal duct (green arrow) can be found.

radiation ran from the lateral geniculate nucleus to the calcarine sulcus (Fig. 3).

Nose. Cat had well-developed olfactory structures that were comprised of a considerably larger olfactory bulb in the cerebrum than human (Fig. 1) (Sebastiani \& Fishbeck). The olfactory sense of cat is approximately 14 times better than of that of human. In a $70 \mathrm{~kg}$ human, the surface area of the olfactory epithelium is approximately $10 \mathrm{~cm}^{2}$. In contrast, a $3 \mathrm{~kg}$ cat has approximately $20 \mathrm{~cm}^{2}$ of olfactory epithelium (Purves et al., 2004).

Cat had a vomeronasal organ duct connecting the rear of the incisors to the lateral side of the nasal septum (Fig. 4).
The vomeronasal organ is known to detect pheromones and control sexual behavior (Døving \& Trotier, 1998).

Mouth. A small salivary gland, the infraorbital gland, which was not found in human, was located in the orbit beneath the eye (Fig. 1B). Cat had the masseter, temporal, lateral pterygoid, and medial pterygoid muscles, as does human. The masticatory muscles were relatively larger than in human (Fig. 1). The maxillary and mandibular nerves were found within the masticatory muscles (Fig. 1C). The inferior alveolar nerve of the mandibular nerve passed through the mandibular canal (Fig. 1B). The ratio of the largest cross length of the trigeminal nerve to that of the brainstem in cat was approximately one-seventh $(1,070$ pixels out of 7,380 pixels $)$, while the ratio in human
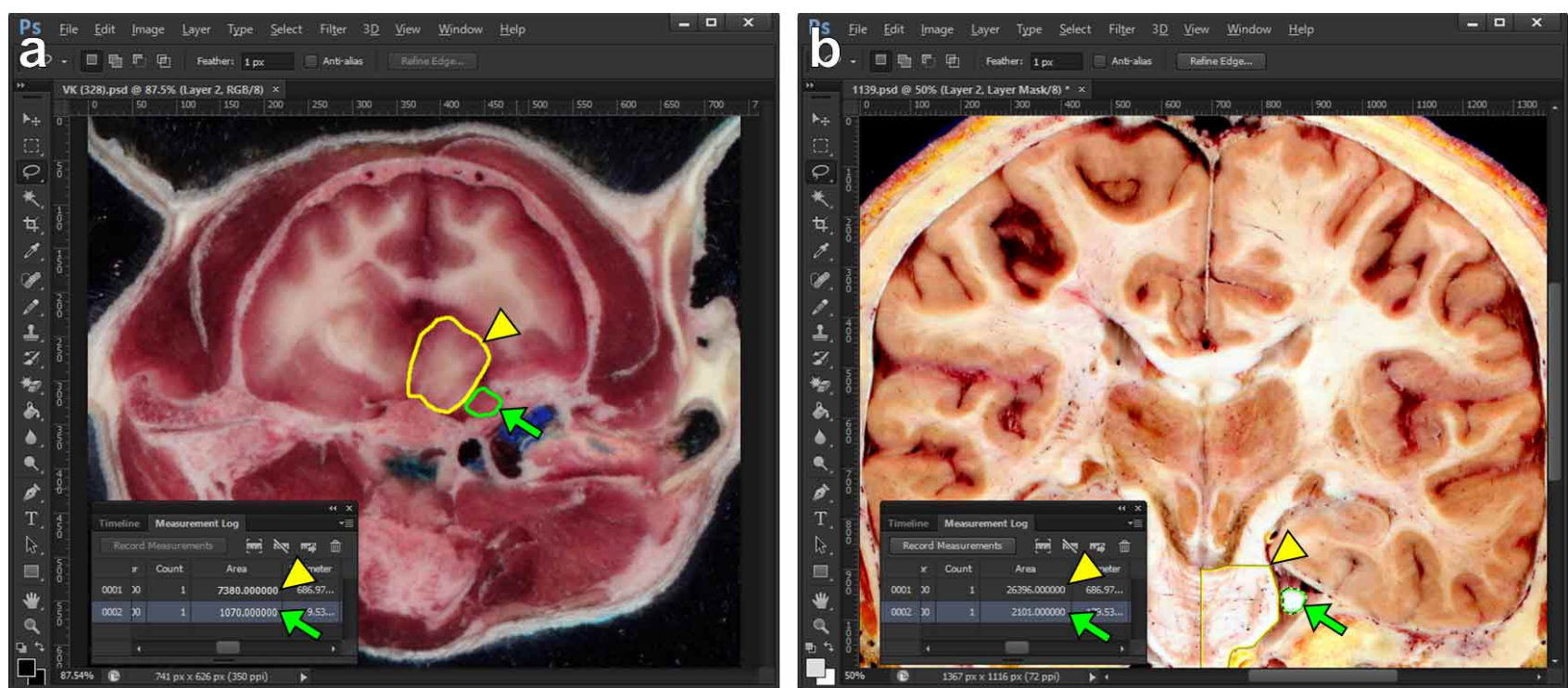

Fig. 5. Size of the brainstem and trigeminal nerve of cat and human. Ratio of the size of the trigeminal nerve (green arrows) to that of the brainstem (yellow arrows) in (a) cat and (b) human are about 1/7 (1,070 pixels / 7,380 pixels) and 1/12 (2,101 pixels / 26,396 pixels), respectively. 
was approximately one-twelfth (2,101 pixels out of 26,396 pixels). This means that the trigeminal nerve of a cat was relatively thick (Fig. 5) (Sebastiani \& Fishbeck). Contrary to human, the cat's maxillary nerve was much thicker than the mandibular nerve (Fig. 1B,C), because the long whiskers around cat nose are well innervated by the maxillary nerve (Gordon et al., 1961).

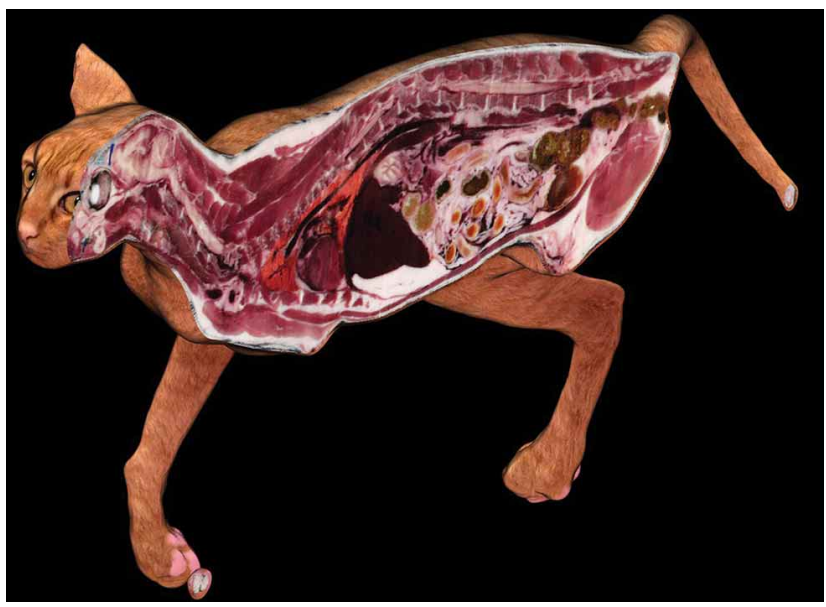

Fig. 6. Volume model of cat whole body of the Anatomage Table ${ }^{\mathrm{TM}}$ made from the sectioned images provided by the authors (Chung et al., 2015).

\section{DISCUSSION}

This is the first report to describe the detailed head structures of a cat on sectioned images with real color and high resolution. Moreover, the morphological characteristics have been explained with the proper physiology of a cat. These minute findings are possible thanks to the state-ofthe-art sectioned images as follows.

First, no fixative or dye is injected; images contain 48 or 24 bit color (Table I), so that original body color was visible. Second, 0.1 or $0.2 \mathrm{~mm}$-sized pixels allow the identification of extremely small structures (e.g., auditory ossicles) (Fig. 1). Third, consistent intervals $(0.2 \mathrm{~mm})$ of the sectioned images enable a structure to be traced from the origin to destination (e.g., visual pathway) (Fig. 3).

Comparative anatomy of the head between cat and human is valuable. This is because the morphology of the human head has been studied widely, whereas there have been fewer studies of a cat's head (Fig. 5).

In this research, the cat head and human head were compared (Fig. 5). The comparison was reliable because the sectioned images of a cat and those of human were manufactured under similar conditions (Park et al., 2009).
On the other hand, the directions of the sectioned images were different in the two species. To overcome the problem, 3D models of the structures of a cat should be compared with those of human. For a future study, the structures will be delineated to acquire segmented images; the segmented images of each structure would be stacked and a $3 \mathrm{D}$ reconstruction will be carried out. The resulting models of a cat will be compared with those of a human to demonstrate the fine topographic anatomy regardless of the sectioning directions (Park et al., 2013).

In detail, the segmented images would produce sophisticated 3D surface and volume models of cat (Park et al., 2013, 2014). The volume model of cat whole body based on these sectioned images is being used in the Anatomage Table ${ }^{\mathrm{TM}}$ (Copyright 2005@ Anatomage, USA; http:// www.anatomage.com), which offers a life-size interactive anatomy visualization (Fig. 6).

For other interested researchers, the sectioned images will be distributed free of charge. An additional goal of this report is to inform other researchers of the methods to establish those raw images. It is expected that other researchers will develop even better sectioned images of cat. The sectioned images and 3D models produced during this research are expected to be viewed as educational and training tools for clinical veterinary medicine.

\section{ACKNOWLEDGEMENTS}

This research was financially supported by the Ministry of Trade, Industry and Energy (MOTIE) and Korea Institute for Advancement of Technology (KIAT) through the International Cooperative R\&D program (Grant number: N0002249).

The authors gratefully acknowledge the support provided by Korea Institute of Science \& Technology Information (KISTI).

CHUNG, B. S.; CHUNG, M. S.; LEE, S.B.; YOUN, C. \& PARK, J. S. Imágenes seccionadas de una cabeza de gato para contribuir al conocimiento de su anatomía seccional. Int. J. Morphol., 36(2):537-543, 2018.

RESUMEN: El conocimiento de la anatomía seccional de cabeza de gato es esencial para interpretar estudios por tomografía computada y resonancia magnética de la región. En el conocimiento de esta anatomía seccional, las imágenes seccionadas de un gato podrían aportar datos bastante efectivos. El objetivo principal con- 
sistió en ayudar a los médicos veterinarios para que aprendan la anatomía seccional de una cabeza de gato mediante la presentación de imágenes seccionadas de alta calidad. Una gata de pelo corto fue congelada y seccionada frontalmente usando un criomicrótomo. Cada sección, con el color real del cuerpo, fue fotografiada con una cámara digital. Los planos frontales se apilaron para producir planos dorsales y sagitales. Las imágenes seccionadas de alta calidad de una cabeza de gato permitieron la identificación de estructuras pequeñas y de dificil visualización. Las estructuras destacadas fueron las siguientes: cada hueso del cráneo, las estructuras del cerebro, la cavidad timpánica (más grande que en el humano), la ventana oval (más grande que en el humano), el nervio vestibular, el nervio coclear, los huesecillos del oído, seis músculos extraoculares, la pupila, el músculo retractor del ojo (no se encuentra en el ser humano), nervio óptico, bulbo olfatorio (considerablemente grande), conducto del órgano vomeronasal (no se encuentra en el ser humano), glándula infraorbitaria (no se encuentra en los humanos), músculos masticatorios (más grandes que en el humano), nervio maxilar (más grande que en el humano) y nervio mandibular. En este trabajo describimos detalladamente, desde el punto de vista de la anatomía seccional, las estructuras de la cabeza de un gato. Las imágenes seccionadas estarán a disponibles para otros investigadores en forma gratuita.

PALABRAS CLAVE: Gato; Cabeza; Anatomía transversal; Proyectos humanos visibles.

\section{REFERENCES}

Bishop, T. M.; Glass, E. N.; De Lahunta, A. \& Shelton, G. D. Imaging diagnosis--masticatory muscle myositis in a young dog. Vet. Radiol. Ultrasound, 49(3):270-2, 2008.

Chung, B. S.; Shin, D. S.; Brown, P.; Choi, J. \& Chung, M. S. Virtual dissection table including the Visible Korean images, complemented by free software of the same data. Int. J. Morphol., 33(2):440-5, 2015.

Dixon, A. K.; Bowden, D. J.; Ellis, H. \& Logan, B. M. Human Sectional Anatomy: Atlas of Body Sections, CT and MRI Images. $4^{\text {th }} \mathrm{ed}$. Boca Raton, CRC Press, 2015. pp.288.

Døving, K. B. \& Trotier, D. Structure and function of the vomeronasal organ. J. Exp. Biol., 201(Pt. 21):2913-25, 1998.

Evans, H. E. \& Alexander, D. E. Miller's Anatomy of the Dog. $4^{\text {th }}$ ed. St. Louis, W. B. Saunders Elsevier, 2012.

Gordon, G.; Landgren, S. \& Seed, W. A. The functional characteristics of single cells in the caudal part of the spinal nucleus of the trigeminal nerve of the cat. J. Physiol., 158(3):544-59, 1961.

Grant, K.; Guéritaud, J. P.; Horcholle-Bossavit, G. \& Tyc-Dumont, S. Anatomical and electrophysiological identification of motoneurones supplying the cat retractor bulbi muscle. Exp. Brain Res., 34(3):541$50,1979$.

Jang, H. G.; Chung, M. S.; Shin, D. S.; Park, S. K.; Cheon, K. S.; Park, H. S. \& Park, J. S. Segmentation and surface reconstruction of the detailed ear structures, identified in sectioned images. Anat. Rec. (Hoboken), 294(4):559-64, 2011.

Kang, B. T.; Ko, K. J.; Jang, D. P.; Han, J. Y.; Lim, C. Y.; Park, C.; Yoo, J. H.; Kim, J. W.; Jung, D. I.; Kim, Y. B.; Woo, E. J.; Cho, Z. H. \& Park, H. M. Magnetic resonance imaging of the canine brain at 7 T. Vet. Radiol. Ultrasound, 50(6):615-21, 2009.

Lauridsen, H.; Hansen, K.; Wang, T.; Agger, P.; Andersen, J. L.; Knudsen, P. S.; Rasmussen, A. S.; Uhrenholt, L. \& Pedersen, M. Inside out: modern imaging techniques to reveal animal anatomy. PLoS One, 6(3):e17879, 2011.

Nowinski, W. L.; Chua, B. C.; Qian, G. Y. \& Nowinska, N. G. The human brain in 1700 pieces: design and development of a three-dimensional, interactive and reference atlas. J. Neurosci. Methods, 204(1):44-60, 2012.

Park, H. S.; Chung, M. S.; Shin, D. S.; Jung, Y. W. \& Park, J. S. Accessible and informative sectioned images, color-coded images, and surface models of the ear. Anat. Rec., 296(8):1180-6, 2013.

Park, H. S.; Shin, D. S.; Cho, D. H.; Jung, Y. W. \& Park, J. S. Improved sectioned images and surface models of the whole dog body. Ann. Anat., 196(5):352-9, 2014.

Park, J. S.; Chung, M. S.; Hwang, S. B.; Lee, Y. S.; Har, D. H.; Park, H. S. Visible Korean Human: improved serially sectioned images of the entire body. I. E. E. E. Trans. Med. Imaging, 24(3):352-60, 2005.

Park, J. S.; Chung, M. S.; Park, H. S.; Shin, D. S.; Har, D. H.; Cho, Z. H.; Kim, Y. B.; Han, J. Y. \& Chi, J. G. A proposal of new reference system for the standard axial, sagittal, coronal planes of brain based on the serially-sectioned images. J. Korean Med. Sci., 25(1):135-41, 2010.

Park, J. S.; Chung, M. S.; Shin, D. S.; Har, D. H.; Cho, Z. H.; Kim, Y. B.; Han, J. Y. \& Chi, J. G. Sectioned images of the cadaver head including the brain and correspondences with ultrahigh field 7.0 T MRIs. Proc. I. E. E. E., 97(12):1988-96, 2009.

Purves, D.; Augustine, G. J.; Fitzpatrick, D.; Katz, L. C.; LaMantia, A. S.; McNamara, J. O. \& Williams, S. M. Olfactory Perception in Humans. $3^{\text {rd }}$ ed. Sunderland, Sinauer Associates Inc., 2004.

Rivero, M. A.; Ramírez, J. A.; Vázquez, J. M.; Gil, F.; Ramírez, G. \& Arencibia, A. Normal anatomical imaging of the thorax in three dogs: computed tomography and macroscopic cross sections with vascular injection. Anat. Histol. Embryol., 34(4):215-9, 2005.

Schiemann, T.; Freudenberg, J.; Pflesser, B.; Pommert, A.; Priesmeyer, K.; Riemer, M.; Schubert, R.; Tiede, U. \& Höhne, K. H. Exploring the Visible Human using the VOXEL-MAN framework. Comput. Med. Imaging Graph., 24(3):127-32, 2000.

Sebastiani, A. M. \& Fishbeck, D. W. Mammalian Anatomy the Cat. $2^{\text {nd }}$ ed. Englewood, Morton Publishing Company, 2005.

Spitzer, V. M. \& Whitlock, D. G. National Library of Medicine: Atlas of the Visible Human Male: Reverse Engineering of the Human Body. Burlington, Bartlett Learning, 1997.

Spitzer, V. M. \& Scherzinger, A. L.Virtual anatomy: an anatomist's playground. Clin. Anat., 19(3):192-203, 2006.

Taeymans, O.; Dennis, R. \& Saunders, J. H. Magnetic resonance imaging of the normal canine thyroid gland. Vet. Radiol. Ultrasound, 49(3):23842, 2008.

Weidner, S.; Probst, A. \& Kneissl, S. MR anatomy of salivary glands in the dog. Anat. Histol. Embryol., 41(2):149-53, 2012.

Wilcox, J. G. \& Barlow, H. B. The size and shape of the pupil in lightly anaesthetized cats as a function of luminance. Vision Res., 15(12):1363$5,1975$.

\section{Corresponding author: \\ Jin Seo Park \\ Department of Anatomy \\ Dongguk University School of Medicine \\ 87 Dongdae-ro, \\ Gyeongju, 38067 \\ REPUBLIC OF KOREA}

\section{E-mail: park93@dongguk.ac.kr}

Received: 26-12-2017

Accepted: $29-01-2018$ 